\title{
Aetiological profile of non-traumatic epistaxis: a two-year retrospective analysis in a tertiary care hospital
}

\author{
Najmudheen Manappattu, N. K. Bashir*, Girish Raj
}

Department of ENT, MES Medical College, Perinthalmanna, Malappuram, Kerala, India

Received: 13 December 2018

Accepted: 29 January 2019

\author{
*Correspondence: \\ Dr. N. K. Bashir, \\ E-mail: bashirnk@gmail.com
}

Copyright: ( $)$ the author(s), publisher and licensee Medip Academy. This is an open-access article distributed under the terms of the Creative Commons Attribution Non-Commercial License, which permits unrestricted non-commercial use, distribution, and reproduction in any medium, provided the original work is properly cited.

\section{ABSTRACT}

Background: Epistaxis is one of the commonest rhinological emergencies. Studies from different parts of the world show wide variation in aetiological profile. Idiopathic epistaxis is the most common form in most western studies while in many developing countries trauma is the predominant factor. Rhinosporidiosis is an important cause for epistaxis in certain parts of Malappuram district of Kerala. Hence this study was designed to analyze the nontraumatic causes for epistaxis in study location with a special emphasis on age and sex distribution and the role of rhinosporidium in epistaxis.

Methods: Retrospective analysis of case records of epistaxis patients was done in a tertiary care teaching hospital in Malappuram district of Kerala, India. Patients with epistaxis reported through OP, IP and referrals from other departments were included as the study population. Age and sex distribution of idiopathic epistaxis and systemic and local cause of epistaxis with its age and sex distribution were analysed.

Results: Total of 110 patients were studied, 74 males and 36 females, between the ages of 4 and 80 . Predominant age group was 11-20 years followed by 21-30, with male dominance in almost all age ranges. Right side predominance was noted in unilateral cases. Thirty six patients had primary epistaxis. Among the systemic causes, 15 had hypertension, four platelet dysfunction and three altered coagulation. Local causes were found in 51 cases; rhinosporidiosis being the commonest followed by infection.

Conclusions: Non-traumatic epistaxis is more common among young males. Nasal rhinosporidiosis and infection are the two prominent local causes for epistaxis.

Keywords: Epistaxis, Rhinosporidiosis, Etiology, Trauma, Idiopathic

\section{INTRODUCTION}

Epistaxis or nosebleed is a common complaint in ENT as well as general practice present as a chronic emergency problem of recurrent bleeds or may be a symptom of a generalized disorder. It is one of the most common otolaryngological emergencies which often require admission to the hospital. It cannot only affect the hemodynamic but may cause great anxiety to patients and their relatives. Worldwide, it is estimated to occur in $60 \%$ of the individuals during their lifetime, with less than $10 \%$ requiring hospital admission. ${ }^{1}$ It affects all age groups and both sexes. Generally, males are slightly affected than females until the age of 50, and epistaxis is more frequent before the age of 10 years and after 4 th decade of life. ${ }^{2}$

The etiological profile of epistaxis has been reported to vary with age and anatomical location. ${ }^{3}$ Based on the site of origin, epistaxis can be classified as anterior and posterior epistaxis. Anterior epistaxis is more common and usually arises either from kiesselbach's plexus or from a vein. ${ }^{4}$ As the bleeding site is accessible, anterior epistaxis which occurs more frequently in children and young adults is rarely severe. On the other hand, posterior epistaxis arises from the area supplied by a 
sphenopalatine artery (SPA) in the posterior part of the nasal cavity, which is more frequent in older adults. Traumatic epistaxis is more common in younger individuals (under age 35 years) and is most often due to digital trauma, facial injury, or a foreign body in the nasal cavity. ${ }^{5}$ Non-traumatic epistaxis is more characteristic of older patients (over age 50 years) and may be due to organ failure, neoplastic conditions, inflammation, or environmental factors (temperature, humidity, altitude). ${ }^{6}$

Epistaxis can be due to both systemic and local factors, although even this distinction is difficult to make and the term "idiopathic epistaxis" is ultimately used in about 80 $90 \%$ of the cases. ${ }^{7}$ Local causes include inflammatory, infective, traumatic, anatomical (deviated nasal septum, septal spur), chemical, or climatic changes, neoplasm, and foreign body. Systemic causes of epistaxis include vascular heart disease, hypertension, coagulation disorders and renal or liver disease. Chronic obstructive pulmonary disease, excessive coughing, nose blowing habit, benign prostatic hyperplasia, straining in constipation and heavy objects lifting may aggravate the epistaxis.

Treatment requires a methodical approach according to cause, site and severity of bleeding. Both conservative and surgical interventions may provide the right treatment option. Most of the underlying causes of epistaxis are preventable. A clearer understanding of the causes, treatment and outcome of these patients is essential for the establishment of preventive strategies as well as treatment guidelines. The aetiology of epistaxis is diverse and multifactorial and shows wide geographical variation. Unlike in the Western literature, a significant proportion of epistaxis in this part of Kerala is accounted by rhinosporidiosis. It is a chronic granulomatous disease affecting both man and animals. A high incidence is reported from Malappuram district of Kerala where the present study is conducted.

\section{METHODS}

A retrospective study was conducted by reviewing the case records of patients with epistaxis for the period of 2 years, from 2010 to 2012 in the department of ENT at MES medical college hospital, tertiary care teaching hospital in Malappuram district of Kerala, India. Patients with epistaxis reported through OP, IP and referrals from other departments were considered. Those due to trauma and cases with incomplete workup were excluded from the study. In this study, patients with epistaxis were retrospectively analyzed for age and gender distribution, symptoms, residence location, and etiological profiling. Age and sex distribution of idiopathic epistaxis and systemic and local cause of epistaxis with its age and sex distribution were also analysed. Records of consultation and opinion of the cardiologist, endocrinologist, and nephrologists which were noted were obtained from the case records for confirming the etiological considerations. The results of this study were shown by descriptive statistics and presented as percentages.

\section{RESULTS}

The study included 110 patients; 74 males and 36 females with Male to Female ratio of 2:1 (Table 1). From this, 98 patients belonged to the Malappuram district of Kerala. Others were from neighbouring district of Palghat, Wynad and Trichur. The age ranged from 4 to 80 years with a mean age of 32.8 years. The highest number of patients belonged to 11-20 age group (25, i.e. $22.7 \%$ ), closely followed by 21-30 range (19 patients) as shown in Table 1. Male predominance was noticed in almost all age range. Childhood epistaxis occurring below 16years of age alone constituted $27.2 \%$.

Table 1: Age and sex distribution.

\begin{tabular}{|lllllllllll|}
\hline \hline Age (in years) & $\mathbf{0 - 1 0}$ & $\mathbf{1 1 - 2 0}$ & $\mathbf{2 1 - 3 0}$ & $\mathbf{3 1 - 4 0}$ & $\mathbf{4 1 - 4 0}$ & $\mathbf{5 1 - 6 0}$ & $\mathbf{6 1 - 7 0}$ & $\mathbf{7 1 - 8 0}$ & Total \\
\hline Male & 8 & 14 & 9 & 16 & 10 & 8 & 3 & 5 & 73 \\
\hline Female & 6 & 11 & 9 & 3 & 2 & 2 & 4 & 0 & 37 \\
\hline Total & 14 & 25 & 18 & 19 & 12 & 10 & 7 & 5 & 110 \\
\hline Percentage & 12.7 & 22.7 & 16.4 & 17.3 & 10.9 & 9.1 & 6.4 & 4.5 & \\
\hline
\end{tabular}

Table 2: Aetiological profile.

\begin{tabular}{|lll|}
\hline Actiology & Number of patients & Percentage \\
\hline Idiopathic & 36 & 32.7 \\
\hline Systemic & 22 & 20 \\
\hline Local & 51 & 46.3 \\
\hline Factitious & 1 & 0.91 \\
\hline
\end{tabular}

Eighty two patients suffered unilateral nasal bleeding; Out of these $47(57.3 \%)$ were on the right side and 39 $(47.5 \%)$ on the left side. The proportion of local, systemic and idiopathic causes of epistaxis observed in the present study is shown in Table 2. There were 36 cases of idiopathic epistaxis. It was twice as common in males as in females (M:F ratio 2:1). Majority of them $(91.7 \%)$ were under the age of 50 , with the highest incidence (17 patients) below the age of 20 (Table 3 ).

A systemic aetiology for the epistaxis was detected in 22 patients, the commonest being hypertension (in 15 cases, $13.6 \%$ ) (Table 4). A vast majority of them (80\%) were elderly over the age of 50 (Table 5). Four patients had platelet dysfunction; 3 aspirin-induced and one due to 
chronic ITP. Three patients bled due to altered coagulation: 2 cirrhosis and one chronic renal failure. Local causes found in our study are shown in Table 6. It contributed to epistaxis in nearly half of our patients (51patients). Among these, nasal rhinosporidiosis is the commonest, found in as many as 25 patients. Here also male predominance (M:F ratio 2.6:1) is seen (Table 7). All except three patients were below the age of 50. The second common local cause is Infection, seen in 19 patients with a more or less equal incidence among males and females (sex ratio, 1:1). Here more than half are children (11 patients) (Table 8). We encountered one young male with factitious nose-bleed which did not fit into any of the above categories.

\section{Table 3: Age and sex distribution of idiopathic epistaxis.}

\begin{tabular}{|c|c|c|c|c|c|c|c|}
\hline $\begin{array}{l}\text { Age (in } \\
\text { years) }\end{array}$ & $\begin{array}{l}0- \\
10\end{array}$ & $\begin{array}{l}11- \\
20\end{array}$ & $\begin{array}{l}21- \\
30\end{array}$ & $\begin{array}{l}31- \\
40\end{array}$ & $\begin{array}{l}41- \\
50\end{array}$ & $\begin{array}{l}51- \\
60\end{array}$ & $\begin{array}{l}\text { 61- } \\
70\end{array}$ \\
\hline Male & 4 & 4 & 3 & 7 & 4 & 1 & 1 \\
\hline Female & 1 & 8 & 1 & 0 & 1 & 0 & 1 \\
\hline $\begin{array}{l}\text { No. of } \\
\text { patients }\end{array}$ & 5 & 12 & 4 & 7 & 5 & 1 & 2 \\
\hline
\end{tabular}

Table 4: Systemic causes for epistaxis

\begin{tabular}{|lll|}
\hline Systemic cause & No. of patients & $\%$ \\
\hline Hypertension & 15 & 13.6 \\
\hline Cirrhosis & 2 & 1.8 \\
\hline Chronic renal failure & 1 & 0.9 \\
\hline Antiplatelet medication & 3 & 2.7 \\
\hline Chronic ITP & 1 & 0.9 \\
\hline
\end{tabular}

Table 5: Hypertension

\begin{tabular}{|lll|}
\hline Age (in years) & $<50$ & $>\mathbf{5 0}$ \\
\hline No. of patients & 3 & 12 \\
\hline
\end{tabular}

Table 6: Local causes.

\begin{tabular}{|lll|}
\hline Local causes & No. of patients & $\%$ \\
\hline Rhinosporidiosis & 25 & 22.7 \\
\hline Infections & 19 & 17.3 \\
\hline Septal spur & 3 & 2.73 \\
\hline Septal perforation & 1 & 0.91 \\
\hline Septal angioma & 1 & 0.91 \\
\hline Sino-nasal malignancy & 1 & 0.91 \\
\hline Foreign body nose & 1 & 0.91 \\
\hline
\end{tabular}

Table 7: Rhinosporidiosis age/sex distribution.

\begin{tabular}{|lllllll|}
\hline $\begin{array}{l}\text { Age (in } \\
\text { years) }\end{array}$ & $\mathbf{0 - 1 0}$ & $\mathbf{1 1 -}$ & $\mathbf{2 1 -}$ & $\mathbf{3 1 -}$ & $\mathbf{4 1 -}$ & $\mathbf{5 1 -}$ \\
Male & 0 & 3 & 5 & 6 & 1 & 3 \\
\hline Female & 0 & 0 & 3 & 3 & 1 & 0 \\
\hline Total & 0 & 3 & 8 & 9 & 2 & 3 \\
\hline
\end{tabular}

Table 8: Infection.

\begin{tabular}{|llllll|}
\hline $\begin{array}{l}\text { Age (in } \\
\text { years) }\end{array}$ & $\mathbf{0 - 1 0}$ & $\mathbf{1 1 - 2 0}$ & $\mathbf{2 1 - 3 0}$ & $\mathbf{3 1 - 4 0}$ & Total \\
\hline Male & 4 & 3 & 2 & 1 & 10 \\
\hline Female & 4 & 1 & 4 & 0 & 9 \\
\hline Total & 8 & 4 & 6 & 1 & 19 \\
\hline
\end{tabular}

\section{DISCUSSION}

Epistaxis is an extremely common symptom of many diverse disease conditions and is probably the commonest rhinological emergency. In Scottish study epistaxis alone accounted for $33 \%$ of all ENT emergency admissions. ${ }^{8}$ Hippocrates in the $5^{\text {th }}$ century BC described the wellknown method of pinching ala nasi as an effective treatment for epistaxis. Nasal mucosa enjoys dual blood supply through internal and external high-pressure carotid system, with rich anastomoses between their branches.

The present study shows that epistaxis mainly affects a younger population with a maximum incidence between the ages of 11-20 years. This tallies with the findings of Razdan et al. ${ }^{9}$ While some argue that epistaxis is a disease of the young, others like Pallin describes a bi-modal agedistribution with a childhood peak below ten years and the other in elderly aged 70-79. ${ }^{10,11}$ Slight male predominance for epistaxis is documented in most series. ${ }^{12}$ In our study males are affected more than twice compared to women. Gilyoma et al reported a similar male to female ratio of $2: 1 .^{13}$

The causes of epistaxis can be local or systemic. But many a time bleeding arises from an artery or a vein without any discernible pathology and is termed as idiopathic. The diagnosis of idiopathic epistaxis requires a detailed evaluation to exclude all known causes. We, in our series, found $32.7 \%$ to be idiopathic. Varshney and Saxena have reported a similar incidence $(35.23 \%){ }^{14}$ Nonetheless Stell from England quotes a higher figure of 70-80\%. ${ }^{15}$ Systemic causes for epistaxis include hypertension, haematological disorders, liver diseases, chronic renal failure etc.

Hypertension has long been considered as an important aetiological factor for epistaxis. Richard et al have concluded that epistaxis is a true symptom of hypertension. ${ }^{16}$ Varshney et al showed that cardiovascular causes (hypertension, atherosclerosis etc.) are the second common cause for epistaxis while Iseh et al placed it at the third position. ${ }^{14,17}$ In our review hypertension was the most common systemic cause. Though it is not well documented how hypertension causes epistaxis, Monckeberg's sclerosis and progressive replacement of muscle tissue by collagen in the tunica media of vessels may contribute to the damage despite the plausible association between the two; many studies fail to prove a direct causal relationship between hypertension and epistaxis. 18 
Deficiencies in vitamin $\mathrm{K}$, whether from liver disease, medications or diet reduces the synthesis of factors II, VII, IX and X. ${ }^{19}$ Malik and Bhatia documented $1 \%$ liver diseases in their series. ${ }^{20}$ Underlying cirrhosis was the cause of bleeding in $1.8 \%$ of our patients. Aspirin and other NSAIDs have been associated with epistaxis by altering the cyclo-oxygenase pathway. ${ }^{21}$ Aspirin use led to epistaxis in $2.7 \%$ of our patients. In more than onethird of our patients, we could elicit a local pathology. Among this rhinosporidiosis was the leading cause. It is a disease caused by Rhinosporidium seeberi. Often epistaxis is the early presentation and histopathology of the typical 'strawberry' mass is diagnostic.

Although this disease is reported from about 70 countries, the highest incidence has been from India and Srilanka. ${ }^{22}$ In India it is predominantly endemic in states of Kerala and Tamil Nadu. A recent study by the co-author has confirmed the endemic nature of rhinosporidium in Malappuram district of Kerala. ${ }^{23}$ Patients with acute rhinosinusitis are more prone to epistaxis because the mucosa here is inflamed and more friable. ${ }^{24}$

In this study, the second common local factor was infections. Our finding correlates with that shown by Varshney $(19.3 \%) .{ }^{14}$ Out of this $42 \%$ were children below ten years. Children are more susceptible to nosebleeds due to extensive vascular supply of nasal mucosa and increased the frequency of URTI. ${ }^{25}$ Peak prevalence is reported in three to eight years age group. ${ }^{26}$ Septal spurs caused epistaxis in 3 cases. Spurs and deflections of nasal septum create airway turbulence on the mucosa anterior to the deformity which predisposes to drying and increased mucosal disruption. Nasal foreign body caused epistaxis in $0.9 \%$. This correlates with the $1 \%$ reported by Razdan. ${ }^{9}$

\section{CONCLUSION}

It may be concluded from our study that non-traumatic epistaxis is more common among young males. An underlying local pathology is found in nearly half of the patients. Nasal rhinosporidiosis and infection are the two important local aetiological factors of epistaxis in our area. A clear awareness about the geographical and demographical variation in aetiology help early identification and management of epistaxis.

\section{ACKNOWLEDGEMENTS}

Authors are thankful to MES Medical College and Medi research direct for their support during the entire project.

Funding: No funding sources

Conflict of interest: None declared

Ethical approval: The study was approved by the Institutional Ethics Committee

\section{REFERENCES}

1. Laflamme L, Monárrez-Espino J, Johnell K, Elling B, Möller J. Type, number or both? A populationbased matched case-control study on the risk of fall injuries among older people and number of medications beyond fall-inducing drugs. PLoS One. 2015;10(3):123390.

2. Lopez A, Cacoub P, Macdougall IC, Peyrin-Biroulet L. Iron deficiency anaemia. Lancet. 2016;387(10021):907-16.

3. Chauhan JP, Singh AB, Kumar A. A Prospective Analysis of Etiology and Efficacy of Various Treatment Modalities Used in Epistaxis at a Tertiary Care Teaching Hospital. Ind J Basic Applied Med Res. 2016;5:750-5.

4. Parajuli R. Evaluation of etiology and treatment methods for epistaxis: a review at a tertiary care hospital in central Nepal. Int $\mathbf{J}$ Otolaryngol. 2015;2015.

5. Shah WA, Amin P, Nazir F. Epistaxis-etiological profile and treatment outcome at a tertiary care centre. J Evolution Med Dental Sci. 2015;4(3):520410.

6. Singh V, Singhal RK. Etiology and Treatment Outcome of Epistaxis at Medical College in Western UP-A Prospective Review of 52 Patients. Int J Contemporary Surg. 2014;2(1):35.

7. Byrne JV. Embolisation for Epistaxis. In: Tutorials in Endovascular Neurosurgery and Interventional Neuroradiology. Springer, Cham; 2017.

8. Walker TWM, Macfarlane TV, McGarry GW. The epidemiology and chronobiology of epistaxis: an investigation of Scottish hospital admissions, 19952004. Clin Otolaryngol. 2007;32:361-5.

9. Razdan U, Rai Zada RM, Chaturvedi VN. Epistaxis: Study of aetiology, site and side of bleeding. Indian J Med Sci. 1999;53:545-52.

10. Eziyi JAE, Amusa YB, Eziyi, AK. Epistaxis in Nigerians. East and Central J Surg. 2009;14(2):93-4.

11. Pallin DJ, Chng Y, McKay MP, Emond JA, Pelletier AJ, Camargo CA: Epidemiology of epistaxis in US emergency departments, 1992 to 2001. Ann Emerg Med. 2005;46:77-81.

12. Padgham N. Epistaxis anatomical and clinical correlates. J Laryngd Otol. 1990;104:308-11.

13. Gilyoma JM, Chalya PL. Etiological profile and treatment outcome of epistaxis at a tertiary care hospital in Northwestern Tanzania: a prospective review of 104 cases. BMC Ear Nose Throat Disor. 2011;11:8.

14. Varshney S, Saxena RK. Epistaxis: a retrospective clinical study. Ind J Otolaryngol Head Neck Surg. 2005;57:125-9.

15. Stell PM. Epistaxis. Clin Otolaryngol.1977;2:26373.

16. Charles R, Corrigan E. Epistaxis and Hypertension. Postgrad Med J. 1977;53:260-1. 
17. Iseh KR, Muhammad Z. Pattern of epistaxis in Sokoto, Nigeria: A review of 72 cases. Ann Afr Med. 2008;7:107-11

18. Lubianca-Neto JF, Bredemeir M, Carvahal EF, Arruda CA, Estrella E, Pletsch A, et al. A study of the assocaiation between epistaxis and the severity of hypertension. Am J Rhinol. 1998;12:269-72.

19. Cummings CW, Haughey BH, Thomas JR, Harker LA, Robbins KT, Schuller DE, et al. Cummings Otolaryngology Head and Neck Surgery. 4th ed. Philadelphia, PA: Elsevier Mosby; 2005: 942-945.

20. Malik MK, Bhatia BPR. Epistaxis a study of 600 patients. Indian Medical Gazette. 1978;112:56-9.

21. Livessy JR, Watson MG, Kelly PJ, Kesteven PJ. Do patients with epistaxis have drug induced platelet dysfunction? Clin otolaryngol. 1995;20:407.

22. Arseculeratne SN. Recent advances in rhinosporidiosis and rhinosporidium seeberi. Indian J Med Microbiol. 2002;20:119-31.
23. Ahmed NA, Mohammed S, Raj G. Rhinosporidiosis: an epidemiological study. J Evolution Med Dental Sci. 2013;2(38):7227-33.

24. Watkinson JC. Scott-Brown's Otolaryngology. 6th ed. Volume 4. 2018: 1-6.

25. Petruson B. Epistaxis in Childhood Rhinology. Rhinology. 1979;17:83-90.

26. Juselius H. Epistaxis: A Clinical study of 1724 patients. J Laryngol Otol. 1974;88:317-7.

Cite this article as: Manappattu N, Bashir NK, Raj G. Aetiological profile of non-traumatic epistaxis: a two-year retrospective analysis in a tertiary care hospital. Int J Otorhinolaryngol Head Neck Surg 2019;5:440-4. 